\title{
Oral hygiene and periodontal status among Terapanthi Svetambar Jain monks in India
}

\section{Manish Jain(b) \\ Anmol Mathur(b) \\ Santhosh Kumar (a) \\ Prabu Duraiswamy(b) \\ Suhas Kulkarni(b)}

(a) BDS; (b)MDS - Department of Preventive \& Community Dentistry, Darshan Dental College and Hospital, Udaipur, Rajasthan, India.

\section{Corresponding author:}

Manish Jain

Department of Preventive \& Community

Dentistry, Darshan Dental College and

Hospital

Loyara Udaipur, Rajasthan, India

313001

E-mail: manrescommunity@yahoo.com

\begin{abstract}
The main objective of the study was to determine the oral hygiene levels and periodontal status among Jain monks attending a Chaturmass in Udaipur, India. To date, no study has been conducted on Jain monks. The study comprises of 180 subjects and the overall response rate was $76 \%$ among them. Oral hygiene status was assessed by the Simplified Oral Hygiene Index (OHI-S) of Greene, Vermillion ${ }^{14}$ (1964), and periodontal status was assessed by the Community Periodontal Index. Additional information was collected regarding food habits, education level and oral hygiene habits. Analysis of variance (ANOVA), Chi Square Test and Step-wise multiple linear regression analysis were carried out using SPSS Software (11.0). The results showed that the oral hygiene status of Jain monks was poor and only $5.6 \%$ of the subjects had good oral hygiene. Overall periodontal disease prevalence was $100 \%$ with bleeding and shallow pocket contributing a major part (72.8\%) among all the age groups $(\mathrm{p}<0.001)$. Multiple linear regression analysis revealed that oral hygiene habits, caloric intake and education level explained a variance of $11.7 \%$ for the Oral hygiene index collectively. The findings confirmed that Jain monks have poor oral hygiene and an increased prevalence of periodontal disease compared to that of the similarly aged general population because, as a part of their religion, many Jain individuals avoid brushing their teeth especially during fasting, keeping in mind not to harm the microorganisms present in the mouth.
\end{abstract}

Descriptors: Oral hygiene; Periodontal diseases; Food habits; Religion. 


\section{Introduction}

Jainism, traditionally known as Jain Dharma, is one of the oldest religions in the world. It is a religion and philosophy originating in ancient India. One of the main characteristics of Jain belief is the emphasis on the immediate consequences of one's behavior. ${ }^{1}$ Jainists are not a part of the Vedic Religion (Hinduism). ${ }^{2,3,4}$ Both streams are subset of the Dharmic family of faith and have existed side by side for many thousands of years, influencing each other. ${ }^{5}$ Jainists are a small but influential religious minority with at least 4.2 million practitioners in modern India. Every year 2000 people from the jain community take diksha in India. In 1986 there were 9,426 monks, which have become 13,947 currently. Out of 13,947 jain monks, 10,654 are Sadhvis because women are taking diksha three times more than men. ${ }^{6}$ The Jain community is the most literate religious community in India, ${ }^{6}$ and the Jain libraries are India's oldest. ${ }^{7}$

The trends of periodontal diseases have seen a rapid change all over the world. Periodontal disease is one of the two major dental diseases that affect human populations worldwide at high prevalence rates. ${ }^{8,9}$ It has been indicated as the main cause of tooth loss in adults over 35 years. ${ }^{10}$

\section{Geographical spread and influence}

Jainism is rapidly expanding in the West as nonIndians follow this religion. With 10 to 12 million followers, ${ }^{11}$ Jainism is among the smallest of the major world religions. Jainists live throughout India; Maharashtra, Rajasthan and Gujarat have the largest Jain population among Indian states.

\section{Classification}

It is generally believed that the jain sangha divided into two major sects, Digambar and Svetambar; Digambar Jain monks do not wear clothes because they believe clothes are like other possessions, increasing the dependency and desire for material things, and desire for anything ultimately leads to sorrow. Svetambar Jain monks wear white seamless clothes for practical reasons. Sadhvis (nuns) of both sects wear white. Svetambaras are further divided into sub-sects, such as Sthanakavasi, Terapanthi and Deravasi. Some are murtipujak (revering statues) while non-murtipujak Jainists refuse statues or images. ${ }^{1}$

\section{Food habits}

Jainism's stance on nonviolence goes far beyond vegetarianism. Jainists refuse food obtained with unnecessary cruelty. Many practice a lifestyle similar to Veganism due to the violence of modern dairy farms, and others exclude root vegetables from their diets in order to preserve the lives of the plants from which they eat. ${ }^{12}$ Potatoes, garlic and onions in particular are avoided by Jainists. ${ }^{13}$ Devout Jainists do not eat, drink, or travel after sunset and prefer to drink water that is first boiled and then cooled to room temperature. Many Jainists do not eat green vegetables and root vegetables once a week.

\section{Oral hygiene habits}

As a part of their religion, many Jain individuals avoid brushing their teeth especially during fasting, keeping in mind not to harm microorganisms present in the mouth. The vows taken by Jain monks and nuns are even more severe with extreme caution in all activities as a principle of non-violence.

The main aims of our study was thus to determine the oral hygiene levels and periodontal status among terapanthi svetambar Jain monks attending a Chaturmass in Udaipur, India, and to correlate them with various demographic variables of the Jain monks, including age, oral hygiene habits, caloric intake and education level.

\section{Material and Methods}

A cross-sectional survey was conducted among Terapanthi Svetambar Jain monks attending Chaturmass in the month of August, 2007, in Udaipur, Rajasthan, India. The study population comprised of 180 Jain monks, with ages from 25-64 years. The overall response rate was $76 \%$. Non-response was due either to systemic illness of the respondent on the day of data collection or to the respondent's refusal to cooperate.

All the subjects who were present on the days of survey were included in the study. Subjects who were uncooperative and systemically ill comprised 
of the exclusion criterion.

Clinical examination was performed by a single trained examiner in a mobile dental unit under artificial light source using standard explorers, mouth mirrors and CPI periodontal probes, and the study was conducted during the first week of October 2007. The oral hygiene variables of each subject were assessed using the Simplified Oral Hygiene Index (OHI-S) of Greene, Vermillion ${ }^{14}$ (1964). The Community Periodontal Index $(\mathrm{CPI})^{15}$ was used to record the periodontal conditions. In addition to clinical data, Education level, Food habits and oral hygiene habits were also integrated through interviews with the person in charge.

Statistical analysis was done with the help of a statistical package for social sciences (SPSS). Analysis of variance (ANOVA) was used to compare between the groups for oral hygiene indicators, namely debris index, calculus index and simplified oral hygiene index. Step-wise multiple regression analysis was used for multiple comparisons where the dependent variables comprised of debris index, calculus index and oral hygiene index. Independent variables consisted of various demographic variables like oral hygiene habits, calorie intake and education level.

According to oral hygiene habits, the subjects were categorized into three groups: 1) those who usually clean their teeth with their fingers after every meal, 2) those who clean their teeth once a day, and 3) those who never clean their teeth or use only oral rinsing.

According to caloric intake, the subjects were categorized into two groups: those whose caloric intake in a whole day was above $1,000 \mathrm{kcal}$ and below $1,000 \mathrm{kcal}$. According to their caloric intake, all the subjects were considered to be malnourished.

According to Jainic Education level, the subjects were categorized into under-graduates and postgraduates. All the subjects were well educated.

Ethical clearance was obtained from the ethical committee of the Darshan Dental College and Hospital before the study was initiated. Informed consent was obtained from the subjects.

\section{Results}

Table 1 shows the oral hygiene status of Jain monks by age groups. Only $5.6 \%$ of the sample had good oral hygiene. The remaining $70 \%$ and $24.4 \%$ had, respectively, fair and poor oral hygiene. The proportion of the sample with poor and fair oral hygiene increased with age.

Table 2 shows that the mean debris and oral hygiene scores were increasing with age. However, the $\mathrm{F}$ value for the mean debris, calculus and $\mathrm{OHI}$ denotes that there was significant variation for the mean debris and calculus levels between the various age groups with the $\mathrm{F}$ value at $62.72(\mathrm{p}<0.001)$ and $6.13(\mathrm{p}=0.003)$ respectively.
Table 1 - Oral hygiene status of Jain monks by age groups.

\begin{tabular}{c|c|c|c|c}
\hline Age group & Number & Good & Fair & Poor \\
\hline $25-34$ years & 40 & $6(15.0 \%)$ & $24(60 \%)$ & $10(25 \%)$ \\
\hline $35-44$ years & 40 & $3(7.5 \%)$ & $26(65 \%)$ & $11(27.5 \%)$ \\
\hline $45-64$ years & 100 & $1(1 \%)$ & $76(76 \%)$ & $23(23 \%)$ \\
\hline Total & 180 & $10(5.6 \%)$ & $126(70 \%)$ & $44(24.4 \%)$ \\
\hline
\end{tabular}

Chi square $=11.902(p=0.018)$.

Table 2 - Mean (SD) DI, Cl and $\mathrm{OHI}-\mathrm{S}$ scores according to the age groups.

\begin{tabular}{c|c|c|c|c}
\hline Age group & Number & $\mathrm{DI}^{*}$ & $\mathrm{Cl}^{* *}$ & OHI-S *** \\
\hline 25-34 years & 40 & $0.577(0.079)$ & $1.51(0.772)$ & $2.08(0.800)$ \\
\hline 35-44 years & 40 & $0.800(0.304)$ & $1.43(0.953)$ & $2.20(0.902)$ \\
\hline $45-64$ years & 100 & $1.13(0.316)$ & $1.08(0.649)$ & $2.21(0.791)$ \\
\hline Total & 180 & $0.935(0.362)$ & $1.25(0.774)$ & $2.18(0.816)$ \\
\hline
\end{tabular}

ANOVA: $\mathrm{F}^{*}=62.72, \mathrm{p}<0.001 ; \mathrm{F}^{* *}=6.13, \mathrm{p}=0.003 ; \mathrm{F}^{* * *}=0.41, \mathrm{p}=0.665$. DI: Debris Index; $\mathrm{Cl}$ : Calculus Index; OHI-S: Simplified Oral hygiene index. SD: Standard Deviation. 
Table 3 presents the CPI scores among Jain monks according to age groups. There were no subjects with healthy periodontal status. Bleeding and shallow pocket were more prevalent among all the age groups. Overall periodontal disease prevalence was $100 \%$, with bleeding and shallow pocket contributing a major part $(72.8 \%)$. There were very few subjects $(8.9 \%)$ with calculus who belonged to the age group of $45-64$ years, and $18.3 \%$ of the subjects presented deep periodontal pockets among the whole sample.

Table 4 shows that more than half of the sextants were with periodontal disease. The mean number of bleeding sextants was greater than the other three periodontal disease indicators. Among these subjects, 5.00 sextants were diseased with shallow pockets involving 2.78 sextants. The mean number of sextants without periodontal disease was 1.00.

Table 5 presents a step-wise multiple linear regression analysis in which the dependent variables were community periodontal index and oral hygiene index. The demographic independent variables were age, oral hygiene habits, caloric intake value and level of education. All the independent variables were significantly associated with the CPI and Oral hygiene index. The CPI showed a great association with caloric intake value. The amount of variation for the CPI with caloric intake value and age was $91.6 \%$ and $2.0 \%$ respectively. The OHI-S showed a great association with oral hygiene habits. The amount of variation for the OHI-S was $7.6 \%, 6.0 \%$ and $3.9 \%$, respectively with oral hygiene habits, caloric intake value and education level.

\section{Discussion}

The accumulation and comparison of data from different studies is difficult because of the scarcity of literature on the oral hygiene status of Jain monks. In the present study, most of the subjects had not been to a dentist in their lifetime for a check-up or treatment. The non-attendance of Jain monks could be due to the principles of Jainism and as a part of their religion. Many Jain individuals avoid dental treatment especially during fasting, keeping in mind not to harm the microorganisms present in their mouths.

The OHI-S index devised by Green and Vermillion (1964) was used to assess the degree of oral hygiene. It was found that the OHI-S index scoring gradually increased with age. In our study, 5.6\%, $70 \%$ and $24.4 \%$ had, respectively, good, fair and poor oral hygiene status. This difference might

\begin{tabular}{|c|c|c|c|c|c|c|c|}
\hline \multirow{6}{*}{$\begin{array}{l}\text { Table } 3 \text { - CPI Scores } \\
\text { among Jain monks } \\
\text { according to age groups. }\end{array}$} & & & & & & & \\
\hline & Age groups & Number & $\begin{array}{c}\text { Healthy } \\
0\end{array}$ & $\begin{array}{c}\text { Bleeding } \\
\mathrm{N}(\%) \\
1\end{array}$ & $\begin{array}{c}\text { Calculus } \\
\mathrm{N}(\%) \\
2\end{array}$ & $\begin{array}{c}\text { Shallow Pocket } \\
\text { N (\%) } \\
3\end{array}$ & $\begin{array}{c}\text { Deep Pocket } \\
\text { N (\%) } \\
4\end{array}$ \\
\hline & $25-34$ years & 40 & 0 & 20 (50\%) & 0 & 20 (50\%) & 0 \\
\hline & $35-44$ years & 40 & 0 & 20 (50\%) & 0 & 19 (47.5\%) & $1 \quad(2.5 \%)$ \\
\hline & $45-64$ years & 100 & 0 & 37 (37\%) & 16 (16\%) & 15 (15\%) & 32 (32\%) \\
\hline & Total & 180 & 0 & 77 (42.8\%) & 16 (8.9\%) & 54 (30\%) & 33 (18.3\%) \\
\hline
\end{tabular}

Table 4 - Mean number (SD) of sextants affected by periodontal conditions in various age groups.

\begin{tabular}{c|c|c|c|c|c|c|c}
\hline Age groups & Number & $\begin{array}{c}\text { Healthy* } \\
0\end{array}$ & $\begin{array}{c}\text { Bleeding** } \\
1+2+3+4\end{array}$ & $\begin{array}{c}\text { Calculus }^{* * *} \\
2+3+4\end{array}$ & $\begin{array}{c}\text { Shallow Pocket } \\
3+4\end{array}$ & $\begin{array}{c}\text { Deep Pocket }^{++} \\
4\end{array}$ & $\begin{array}{c}\text { Excluded }^{+++} \\
X\end{array}$ \\
\hline 25-34 years & 40 & $0.50(0.51)$ & $5.50(0.51)$ & $3.50(0.51)$ & $2.50(0.51)$ & $0.50(0.51)$ & $0.00(0.00)$ \\
\hline $35-44$ years & 40 & $1.50(0.51)$ & $4.50(0.51)$ & $3.50(1.5)$ & $2.50(1.5)$ & $0.50(0.51)$ & $0.50(0.50)$ \\
\hline $45-64$ years & 100 & $1.00(0.90)$ & $5.00(0.90)$ & $3.20(1.9)$ & $3.00(1.9)$ & $0.80(0.75)$ & $1.00(1.2)$ \\
\hline Total & 180 & $1.00(0.82)$ & $5.00(0.82)$ & $3.33(1.6)$ & $2.78(1.6)$ & $0.67(0.67)$ & $0.67(1.06)$ \\
\hline
\end{tabular}

ANOVA: $\mathrm{F}^{*}=17.70, \mathrm{p}<0.001 ; \mathrm{F}^{* *}=17.70, \mathrm{p}<0.001 ; \mathrm{F}^{* * *}=0.894, \mathrm{p}=0.411 . \mathrm{F}^{+}=2.138, \mathrm{p}=0.121 ; \mathrm{F}^{++}=4.658, \mathrm{p}=0.011 ; \mathrm{F}^{+++}=15.618$, $p<0.001$. SD: Standard Deviation. 
Table 5 - Step-wise multiple linear regression analysis with $\mathrm{OHI}-\mathrm{S}$ and $\mathrm{CPI}$ as dependent variables.

\begin{tabular}{|c|c|c|c|c|}
\hline Model & $R$ & $\mathrm{R}^{2}$ & F Value & P Value \\
\hline \multicolumn{5}{|c|}{$\mathrm{CPI}$} \\
\hline 1 & 0.957 (a) & 0.916 & 1959.9 & 0.001 (a) \\
\hline 2 & 0.967 (b) & 0.936 & 1296.6 & 0.001 (b) \\
\hline \multicolumn{5}{|c|}{$\begin{array}{l}\text { a Predictors: (Constant), Caloric intake value } \\
\text { b Predictors: (Constant), Caloric intake value, Age }\end{array}$} \\
\hline \multicolumn{5}{|c|}{$\mathrm{OHI}-\mathrm{S}$} \\
\hline 1 & 0.276 (a) & 0.076 & 14.80 & 0.001 (a) \\
\hline 2 & 0.369 (b) & 0.136 & 14.01 & 0.001 (b) \\
\hline 3 & 0.419 (c) & 0.175 & 12.55 & 0.001 (c) \\
\hline \multicolumn{5}{|c|}{$\begin{array}{l}\text { a Predictors: (Constant), Oral hygiene habits } \\
\text { b Predictors: (Constant), Oral hygiene habits, Caloric intake } \\
\text { value } \\
\text { c Predictors: (Constant), Oral hygiene habits, Caloric intake } \\
\text { value, Education level }\end{array}$} \\
\hline \multicolumn{5}{|c|}{$\begin{array}{l}\text { CPI: Community periodontal index } \\
\text { OHI-S: Simplified Oral hygiene index }\end{array}$} \\
\hline
\end{tabular}

be due to the peculiar oral hygiene habits of Jain monks.

The CPITN has been used extensively for epidemiological surveys and screening in clinical practice for periodontal disease. There has, however, been criticism of the index because of the potential error in overestimating periodontal treatment needs in young individuals and failure to detect some localized severe periodontitis in adults. ${ }^{16}$ The CPITN indicators, however, did give correct estimates of the prevalence of bleeding in a population tested for the index validity.

The present study showed that the periodontal status of the study population was poor with a prevalence rate of $50.0 \%$ and $47.5 \%$ respectively for the bleeding and shallow pocket components in the 35 44 years age group. In a previous study conducted by Guile $^{17}$ (1992) on the population of Saudi Arabia, the prevalence rates for these components were respectively $2.3 \%$ and $26.6 \%$ in the same age group. The higher rates observed in the present study might be due to the poor oral hygiene habits of Jain monks.

The proportion of subjects with bleeding, calculus or pockets for the age group of 35-44 years was $100 \%$, which is greater than that of the general population of Rajasthan state, where the proportion of periodontal disease in the same age group was $83.6 \%$ according to Bali et al. ${ }^{18}$ (2004).

The mean number of healthy sextants in the study population was 1.5 for the age group of 35-44 years, which is less than that of the general population of comparable ages in Rajasthan state, where it was found to be only $1.6 .^{18}$ In the present study, most of the subjects had not been to the dentist for a check-up or treatment.

Bleeding and shallow pocket were widespread in all the age groups. Similar results were observed by Wang et al. ${ }^{19}$ (2002), and destructive periodontitis was less frequent in the 35-44 years age group when compared to the rates observed in other studies. ${ }^{20-23}$

The percentage of individuals with shallow and deep pockets was greater in the age groups of 3544 and 45-64 years. Similar results were observed in studies done by Dini, Guimarães ${ }^{24}$ (1994) in a worker population.

The results of the present study have shown 1.5 mean healthy sextants in the age group of 35-44 years while Mengel et al. ${ }^{25}$ (1996) have observed the same 1.5 healthy sextants in the same age group in the Yemen upland, and Mumghamba et al. ${ }^{26}$ (1996) have found 2.5 in their study.

The mean sextants with deep pockets were 0.5, in accordance with the study done by Buorgeois et al. ${ }^{27}$ (1997) who observed an average of 0.1 sextants in 35-44 yr olds.

The mean number of excluded sextants (0.67) in the surveyed population is in contrast with those found in the general population of South East Asia $(0.0-0.7)$, America $(0.2-0.15)$, Europe $(0.0-1.5)$, Africa $(0.0-0.7)$, the Middle East $(0.0-0.1)$ and the Western Pacific regions $(0.0-0.9)$ and French Polynesia (1.7). ${ }^{28}$

The relationship between nutrition and oral health is multifaceted. Nutrition has both local and systemic impacts on the oral cavity. ${ }^{29}$ While diet and eating patterns have a local effect on the teeth, saliva and soft tissues, the systemic impact of nutrition also has considerable implications. Periodontal diseases, including gingivitis and periodontitis, are serious infections that, if left untreated, can lead to tooth loss. Necrotizing periodontal disease is an infection characterized by necrosis of gingival tis- 
sues, periodontal ligament and alveolar bone. These lesions are most commonly observed in individuals with systemic conditions such as HIV infection, malnutrition and immunosuppression. It has been concluded that early childhood protein-energy malnutrition (ECPEM) is related to the subsequent development of periodontal disease in adolescents and young adults. The present study also concluded that the CPI and OHI-S have a great association with the caloric intake value by Jain monks because, according to their caloric intake, all the Jain monks were considered to be malnourished. The amount of variation for the $\mathrm{CPI}$ and $\mathrm{OHI}-\mathrm{S}$ with caloric intake value was respectively $91.6 \%$ and $6.0 \%$.

In our study, various demographic independent variables like age, oral hygiene habits, caloric intake value and level of education were significantly associated with the CPI and Oral hygiene index. The CPI showed a great association with caloric intake value. The amount of variation for the CPI with caloric intake value and age was respectively $91.6 \%$ and $2.0 \%$. The OHI-S showed a great association

\section{References}

1. Tobias M. Life Force: the world of Jainism. Berkeley (California): Asian Humanities Press; 1991. 117 p.

2. Jaini JL. Jaina Law: Bhadrabahu Samhita. Arrah: Central Jaina Publishing House; 1916.

3. Jaini PS. The Jaina Path to Purification. Delhi: Motilal Banarsidass; 1979.

4. Masih Y. A Comparative Study of Religions. Delhi: Motilal Banarsidass Publ.; 2000.

5. Oldmeadow H, editor. Light from the East: Eastern Wisdom for the Modern West. Delhi: World Wisdom; 2007.

6. Registrar General \& Census Commissioner, India. Census of India 2001. [cited 2008 Nov 12]. Available from: http://www. censusindia.net.

7. Cort JE. The Jain Knowledge Warehouses: traditional libraries in India. J Am Orient Soc. 1995 Jan-Mar;115(1):77-87.

8. Papapanou PN. Epidemiology of periodontal diseases: an update. J Int Acad Periodontol. 1999 Oct;1(4):110-6.

9. Petersen PE. The World Oral Health Report 2003: continuous improvement of oral health in the $21^{\text {st }}$ century - the approach of the WHO Global Oral Health Programme. Community Dent Oral Epidemiol. 2003 Dec;31 Suppl 1:3-23.

10. Hohfeld M, Bernimoulin JP. Application of the community periodontal index of treatment needs (CPITN) in a group of with oral hygiene habits. The amount of variation for the OHI-S was $7.6 \%, 6.0 \%$ and $3.9 \%$, respectively with oral hygiene habits, caloric intake value and education level.

Taking into account the disease status and the available resources for periodontal care in this surveyed population, the priority should be based on a population strategy and primary prevention programs to improve the periodontal health by promoting self care and oral hygiene.

\section{Conclusion}

It was found that Jain monks have poor oral hygiene and an increased prevalence of periodontal disease compared to that of the similarly aged general population because of malnourishment and because of their religion, since many Jain individuals avoid brushing their teeth and visiting the dentist for a check-up or treatment, especially during fasting, keeping in mind not to harm the microorganisms present in the oral cavity.

45-54-year-old German factory workers. J Clin Periodontol. 1993 Sep;20(8):551-6.

11. Basic Faith Group Information. Available from: http:// chaplain.humberc.on.calfgi.pdf\#search $=\% 2215 \% 20$ milli on\%20jains\%22 apud Wikipedia. Available from: http:// en.wikipedia.org/wiki/User:Sarvagnya/Jainism\#cite_note-1. [cited 2008 Nov 12].

12. Viren, Jain. RE Today. Retrieved on 2007-06-14. Available from: http://www.retoday.org.uk/pdfs/dre/viren.pdf apud Wikipedia. Available from: http:/len.wikipedia.org/wiki/ User:Sarvagnya/Jainism\#cite_note-2. [cited 2008 Nov 12].

13. At the Root of Root Vegetables. Anekant Education Foundation. Retrieved on 2007-06-14. [cited 2008 Nov 12]. Available from: http://www.anekant.org/pdf/tott_at-the-root-ofvegetables.pdf.

14. Greene JC, Vermillion JR. The simplified oral hygiene index. J Am Dent Assoc. 1964 Jan;68:7-13.

15. World Health Organization. Oral health surveys: basic methods. $4^{\text {th }}$ ed. Geneva: WHO; 1997.

16. Lindhe J. Text book of clinical periodontology. $2^{\text {nd }}$ ed. Copenhagen: Munksgaard; 1989.

17. Guile EE. Periodontal status of adults in central Saudi Arabia. Community Dent Oral Epidemiol. 1992 Jun;20(3):159-60. 
18. Bali RK, Mathur VB, Talwar PP, Chanana HB. National oral health survey and fluoride mapping 2002-2003. New Delhi: Dental Council of India; 2004.

19. Wang HY, Petersen PE, Bian JY, Zhang BX. The second national survey of oral health status of children and adults in China. Int Dent J. 2002 Aug;52(4):283-90.

20. El Qaderi SS, Quteish Ta'ani D. Assessment of periodontal knowledge and periodontal status of an adult population in Jordan. Int J Dent Hyg. 2004 Aug;2(3):132-6.

21. Garcia ML, Cutress TW. A national survey of periodontal treatment needs of adults in the Philippines. Community Dent Oral Epidemiol. 1986 Dec;14(6):313-6.

22. Oliver RC, Brown LJ, Löe H. An estimate of periodontal treatment needs in the U.S. based on epidemiologic data. J Periodontol. 1989 Jul;60(7):371-80.

23. Pilot T, Barmes DE. An update on periodontal conditions in adults, measured by CPITN. Int Dent J. 1987 Sep;37(3):16972 .
24. Dini EL, Guimarães LO. Periodontal conditions and treatment needs (CPITN) in a worker population in Araraquara, SP, Brazil. Int Dent J. 1994 Aug;44(4):309-11.

25. Mengel R, Eigenbrodt M, Schünemann T, Florès-de-Jacoby L. Periodontal status of a subject sample of Yemen. J Clin Periodontol. 1996 May;23(5):437-43.

26. Mumghamba EG, Markkanen HA, Honkala E. Periodontal status and treatment needs in a rural area of Ukonga, Tanzania. Int Dent J. 1996 Jun;46(3):156-60.

27. Buorgeois D, Hescot P, Doury J. Periodontal conditions in 35-44-yr-old adults in France, 1993. J Periodontal Res. 1997 Oct;32(7):570-4.

28. Miyazaki H, Pilot T, Leclercq M-H. Periodontal profiles: an overview of CPITN Data in the WHO Global Oral Data Bank for the age groups 15-19 years, 35-44 years and 65-74 years. Geneva: WHO; 1992.

29. American Dietetic Association. Position of the American Dietetic Association: oral health and nutrition. J Am Diet Assoc. 1996 Feb;96(2):184-9. 